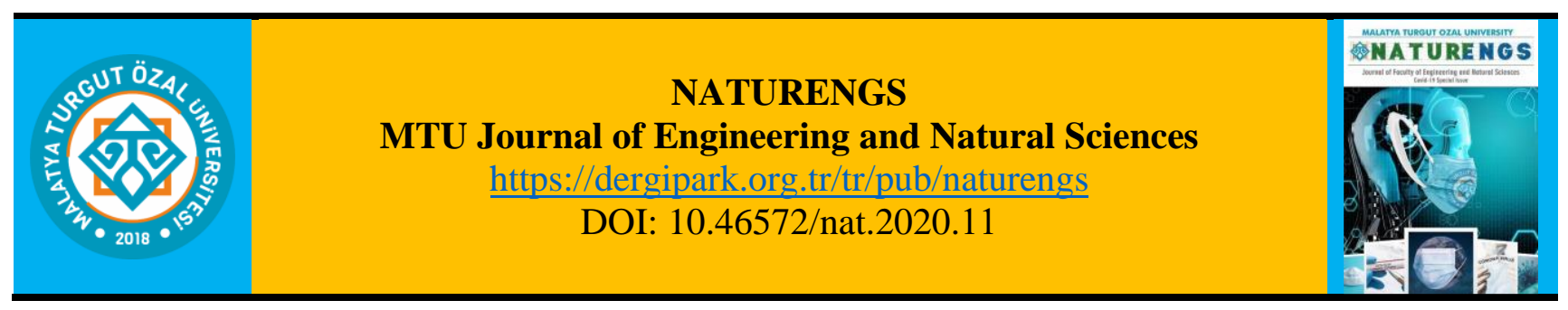

\title{
Opinions of Students About Distance Education in the Pandemi Process
}

\author{
Mustafa AKSOĞAN \\ Akcadağ Vocational School, Malatya Turgut Özal University, Malatya, Turkey.
}

(Received: 06.08.2020; Accepted: 14.08.2020)

\begin{abstract}
While the pandemic process experienced all over the world has caused digital transformations in many areas, it has also caused some obligations in the field of education. Distance education has become an imperative this process in Turkey. Private or public institutions that provide education and training at all levels continued their activities through distance education. This study was carried out to determine student views on distance education. The working group consists of 508 students studying in different faculties and vocational schools of Malatya Turgut Ozal University. The data were collected by a "Student Views on Distance Education" questionnaire prepared by the researcher. According to the results of the research, the participants stated that distance education has a negative effect on their socialization. However, it was observed that the participants' views on distance education were undecided, and men viewed distance education more positively than women.
\end{abstract}

Keywords: Distance learning, Student opinions, Online learning, Pandemic process.

\section{INTRODUCTION}

Rapidly developing information and communication technologies have become an integral part of life both individually and institutionally. In this way, information and communication technologies affect the education sector as well as all sectors. Diversity has occurred in training methods and the obligation of individuals to be together has been eliminated in order to present the information. Especially, the widespread use of the internet and the increase in the number of technological devices connected to the internet enabled the spread of distance education applications. Thus, individuals were provided with a space-independent and flexible learning environment.

The history of distance education goes back nearly 200 years. In 1840, in England, Isaac Pitman laid the foundations of distance education with letter teaching [1]. Letter Education University was established in the United States of America in 1883 and attracted the attention of the public [2]. With the developing technology in the following years, radio, telephone, television, computer and the internet started to be used as distance education tools. Every technological development has led to groundbreaking changes in distance education. These developments have enabled distance education to reach wider audiences and more people to benefit from this education. Today, thanks to internet-connected technological devices, distance education activities can be carried out simultaneously and in mutual communication. Thus, the problem of not being able to give instant feedback to students, who are seen as one of the biggest disadvantages of distance education, has begun to be overcome. Due to these positive aspects, 
distance education has been used in developed and developing countries with an increasing number of applications in recent years.

Distance education generally refers to the education that takes place when teachers and students are physically separated [3]. Distance learning is a learning activity that removes the time and places limits by using special communication methods and presents the learning activities to the users in a planned and designed way [4]. Distance education largely customizes the education process, taking into account individual differences such as learning speed and style [5]. Teachers and students get rid of compulsory workload and individual differences disappear with distance education applications [6]. The success levels increase as the students move more comfortably in the environment in which they take lessons and are not constantly under supervision [7].

For example, the Covid-19 virus, which was seen in Wuhan province of China at the end of 2019, became a global epidemic in a short time, and education, like many sectors, was negatively affected in this process, and educational institutions had to continue their activities with distance education. By preparing the infrastructure as soon as possible universities in Turkey, students were able to keep their distance education activities. This study was carried out in order to determine the opinions of students who had to carry out their educational activities with distance education during the pandemic process.

\section{Purpose of the Research}

The research aims to determine student views on distance education, which is mandatory in higher education institutions during the pandemic process. For this reason, the research has been discussed within the framework of the following sub-problems:

1- What are the general views of the participants on distance education?

2- Is there a significant difference by gender in the general views of the participants on distance education?

3- Is there a significant difference by age in the general views of the participants on distance education?

\section{MATERIAL AND METHODS}

The general screening model was used in the study. The general screening model involves studies on the entire universe or a sample to be taken from it in order to make a general judgment about the universe in a universe consisting of many elements [8].

\subsection{Participant Group}

The population of the research consists of students studying at Malatya Turgut Özal University. Non-random - voluntary sampling method was used for sample selection. This sampling is a voluntary method in which the person or individuals voluntarily participate in the research [9]. The survey link prepared online has been delivered to all students. The sample group of the research consists of 508 students who fill the questionnaire completely. The data regarding the demographic characteristics of the participants are shown in Table 1. 
Table 1. Data on the Demographic Characteristics of the Participants

\begin{tabular}{|c|c|c|c|c|c|}
\hline GENDER & $\mathbf{N}$ & $\%$ & FACULTY / VOCATIONAL SCHOOL & $\mathbf{N}$ & $\%$ \\
\hline Female & 272 & 53.5 & Akcadag Vocational Scool & 46 & 9.1 \\
\hline Male & 236 & 46.5 & Arapgir Vocational Scool & 45 & 8.9 \\
\hline AGE & $\mathbf{N}$ & $\%$ & Battalgazi Vocational Scool & 51 & 10.0 \\
\hline $17-19$ & 67 & 13.2 & Darende Vocational Scool & 79 & 15.6 \\
\hline $20-22$ & 291 & 57.3 & Dogansehir Vocational Scool & 58 & 11.4 \\
\hline $23-25$ & 106 & 20.9 & Hekimhan Vocational Scool & 62 & 12.2 \\
\hline 26 and over & 44 & 8.7 & Kale Vocational Scool & 61 & 12.0 \\
\hline DEVICE & $\mathbf{N}$ & $\%$ & Yesilyurt Vocational Scool & 48 & 9.4 \\
\hline Mobile & 357 & 70.3 & Faculty of Agriculture & 58 & 11.4 \\
\hline Computer & 144 & 28.3 & TOTAL & 508 & 100 \\
\hline Tablet & 7 & 1.4 & & & \\
\hline TOTAL & 508 & 100 & & & \\
\hline
\end{tabular}

As seen in Table 1, the students who participated in the survey consisted of 272 people, women and 236 people. Again, 67 of the participants are between the ages of 17-19, 291 are between the ages of 20-22, 106 are between the ages of 23-25 and 44 are between the ages of 26 and over. Considering the schools in which the participants attend, 79 of them are in Darende Vocational School, 62 of them are in Hekimhan Vocational School, 61 of them are in Kale Vocational School, 58 of them are in Dogansehir Vocational High School and Faculty of Agriculture, 51 of them are in Battalgazi Vocational High School, 48 of them are in Yesilyurt Vocational High School, 46 of them are in Akcadağ Vocational High School. It is seen that there are 45 schools in Arapgir Vocational School. It is seen that $70.3 \%$ of the participants use their mobile phones to connect to the internet.

\subsection{Data Collection Method}

In our study, a questionnaire prepared by the researcher was used to determine the views of students about distance education. During the questionnaire development process, firstly, a literature review was conducted in which student views on distance education were investigated. Later, the items in the questionnaires developed on the subject were reformatted in line with our research questions and an item pool was created. The data obtained were analyzed by the researcher, and 29 attitude statements that were thought to be related to university students' views on distance education were determined. The draft form of the questionnaire consisting of 29 items was submitted for expert opinion to determine the content validity, and some statements were corrected following the recommendations of the experts. In addition, 7 items that were not suitable for the purpose of the study or were difficult to understand were removed from the scale in line with expert opinions.

Due to the interruption of formal education in educational institutions in our country during the pandemic process, it was not possible to reach students face to face. That's why the questionnaire has been published online. The survey consists of three parts. The first part of the survey included demographic information. In the second part of the questionnaire, there are 22 statements to get students' views on distance education. The students were asked to mark to what extent agree (1- minimum agree or disagree, 5- maximum agree) to these statements. In the last part, two open-ended questions are asked to write the positive and negative aspects of distance education. Reliability analysis of the questionnaire used in the study was made and the Cronbach's alpha value was found to be 0.92 . Cronbach's Alpha value must be greater than 0.7 for a reliable survey [10]. Indeed, the value of 0.92 indicates that the survey questions are highly reliable. 


\subsection{Data Analysis}

The data obtained are analyzed with a package program. First of all, in order to examine whether the distribution of the data is normal or not, kurtosis and skewness values were calculated and the results are shown in Table 2.

Table 2. Normality Test Results of Data

\begin{tabular}{|l|c|}
\hline Descriptives & Value \\
\hline Mean & 3.039 \\
\hline Median & 3.091 \\
\hline Variance & 0.764 \\
\hline Std. Deviation & 0.874 \\
\hline Minimum & 1 \\
\hline Maximum & 5 \\
\hline Range & 4 \\
\hline Skewness & -0.263 \\
\hline Kurtosis & -0.043 \\
\hline
\end{tabular}

As seen in Table 2, kurtosis and skewness values are between -1 and +1 values and close to 0 . Based on this result, it can be assumed that the data are distributed normally. Parametric tests were applied as the data showed normal distribution. T-test was conducted to determine whether the data on views on distance education differ by gender, and ANOVA test was conducted to determine whether there was a difference according to age.

\section{RESULTS AND DISCUSSION}

In this section, the answers given by students about distance education and the results of the analysis will be given.

Table 3. Frequency and Percentage Distributions of Students' Answers Regarding Their Views on Education that Prolong the Pandemic Process

\begin{tabular}{|c|c|c|c|c|c|c|c|c|c|c|c|c|}
\hline & \multirow{2}{*}{ Mean } & \multirow{2}{*}{ SD } & \multicolumn{2}{|c|}{1} & \multicolumn{2}{|c|}{2} & \multicolumn{2}{|c|}{3} & \multicolumn{2}{|c|}{4} & \multicolumn{2}{|c|}{5} \\
\hline & & & $\mathbf{N}$ & $\%$ & $\mathbf{N}$ & $\%$ & $\mathbf{N}$ & $\%$ & $\mathbf{N}$ & $\%$ & $\mathbf{N}$ & $\%$ \\
\hline $\begin{array}{l}\text { I was able to access the } \\
\text { course contents quickly } \\
\text { with distance education. }\end{array}$ & 2.98 & 1.351 & 93 & 18.3 & 92 & 18.1 & 153 & 30.1 & 73 & 14.4 & 97 & 19.1 \\
\hline $\begin{array}{l}\text { I think that one of the } \\
\text { advantages of distance } \\
\text { education is the } \\
\text { possibility of continuous } \\
\text { repetition. }\end{array}$ & 3.23 & 1.462 & 101 & 19.9 & 64 & 12.6 & 90 & 17.7 & 123 & 24.2 & 130 & 25.6 \\
\hline $\begin{array}{l}\text { Thanks to distance } \\
\text { education, I was able to } \\
\text { access the necessary } \\
\text { information faster. }\end{array}$ & 2.69 & 1.387 & 135 & 26.6 & 110 & 21.7 & 117 & 23.0 & 70 & 13.8 & 76 & 15.0 \\
\hline $\begin{array}{l}\text { I think that I can learn } \\
\text { faster thanks to distance } \\
\text { education. }\end{array}$ & 2.11 & 1.309 & 235 & 46.3 & 106 & 20.9 & 89 & 17.5 & 30 & 5.9 & 48 & 9.4 \\
\hline $\begin{array}{l}\text { Thanks to distance } \\
\text { education, I was able to } \\
\text { save time and allocate } \\
\text { time for other interests. }\end{array}$ & 3.19 & 1.485 & 107 & 21.1 & 63 & 12.4 & 97 & 19.1 & 106 & 20.9 & 135 & 26.6 \\
\hline
\end{tabular}




\begin{tabular}{|c|c|c|c|c|c|c|c|c|c|c|c|c|}
\hline $\begin{array}{l}\text { I think that distance } \\
\text { education can be used in } \\
\text { every lesson taught with } \\
\text { formal education. }\end{array}$ & 2.31 & 1.463 & 226 & 44.5 & 88 & 17.3 & 76 & 15.0 & 46 & 9.1 & 72 & 14.2 \\
\hline $\begin{array}{l}\text { I regularly followed the } \\
\text { live lessons I took with } \\
\text { distance education. }\end{array}$ & 3.18 & 1.478 & 106 & 20.9 & 68 & 13.4 & 96 & 18.9 & 107 & 21.1 & 131 & 25.8 \\
\hline $\begin{array}{l}\text { I followed the record of } \\
\text { the live lessons I could } \\
\text { not attend. }\end{array}$ & 3.22 & 1.476 & 100 & 19.7 & 75 & 14.8 & 81 & 15.9 & 118 & 23.2 & 134 & 26.4 \\
\hline $\begin{array}{l}\text { I sometimes had } \\
\text { technical problems with } \\
\text { my distance education } \\
\text { site. }\end{array}$ & 3.30 & 1.535 & 110 & 21.7 & 47 & 9.3 & 97 & 19.1 & 87 & 17.1 & 167 & 32.9 \\
\hline $\begin{array}{l}\text { I think distance } \\
\text { education and face to } \\
\text { face education are } \\
\text { equivalent. }\end{array}$ & 2.02 & 1.380 & 281 & 55.3 & 83 & 16.3 & 52 & 10.2 & 39 & 7.7 & 53 & 10.4 \\
\hline $\begin{array}{l}\text { I see distance education } \\
\text { as face-to-face education } \\
\text { supportive. }\end{array}$ & 2.54 & 1.491 & 189 & 37.2 & 82 & 16.1 & 100 & 19.7 & 50 & 9.8 & 87 & 17.1 \\
\hline $\begin{array}{l}\text { The duration of distance } \\
\text { education courses was } \\
\text { sufficient. }\end{array}$ & 3.53 & 1.337 & 65 & 12.8 & 47 & 9.3 & 99 & 19.5 & 149 & 29.3 & 148 & 29.1 \\
\hline $\begin{array}{l}\text { The course materials } \\
\text { used for distance } \\
\text { education courses were } \\
\text { sufficient. }\end{array}$ & 3.34 & 1.366 & 79 & 15.6 & 54 & 10.6 & 114 & 22.4 & 136 & 26.8 & 125 & 24.6 \\
\hline $\begin{array}{l}\text { The lecturers who gave } \\
\text { distance education } \\
\text { lessons were prepared } \\
\text { for the lesson. }\end{array}$ & 3.98 & 1.333 & 46 & 9.1 & 36 & 7.1 & 72 & 14.2 & 83 & 16.3 & 271 & 53.3 \\
\hline $\begin{array}{l}\text { Thanks to distance } \\
\text { education, it was useful } \\
\text { for me to watch the } \\
\text { lessons again. }\end{array}$ & 3.21 & 1.403 & 95 & 18.7 & 57 & 11.2 & 114 & 22.4 & 128 & 25.2 & 114 & 22.4 \\
\hline $\begin{array}{lr}\text { I had } & \text { difficulty } \\
\text { understanding } & \text { the } \\
\text { faculty members in } \\
\text { distance } & \text { education } \\
\text { classes. } & \\
\end{array}$ & 2.58 & 1.341 & 135 & 26.6 & 135 & 26.6 & 109 & 21.5 & 64 & 12.6 & 65 & 12.8 \\
\hline $\begin{array}{l}\text { Announcements and } \\
\text { explanations were made } \\
\text { about the start time of } \\
\text { the courses to be given } \\
\text { by distance education. }\end{array}$ & 3.65 & 1.345 & 59 & 11.6 & 45 & 8.9 & 89 & 17.5 & 136 & 26.8 & 179 & 35.2 \\
\hline $\begin{array}{l}\text { In distance education } \\
\text { classes, I could ask } \\
\text { questions that I could not } \\
\text { understand. }\end{array}$ & 3.75 & 1.342 & 55 & 10.8 & 40 & 7.9 & 85 & 16.7 & 124 & 24.4 & 204 & 40.2 \\
\hline $\begin{array}{l}\text { Distance education } \\
\text { negatively affected my } \\
\text { socialization. }\end{array}$ & 3.11 & 1.635 & 134 & 26.4 & 73 & 14.4 & 83 & 16.3 & 40 & 7.9 & 178 & 35.0 \\
\hline $\begin{array}{l}\text { I prefer distance } \\
\text { education to face to face } \\
\text { education. }\end{array}$ & 1.94 & 1.464 & 329 & 64.8 & 43 & 8.5 & 40 & 7.9 & 29 & 5.7 & 67 & 13.2 \\
\hline $\begin{array}{l}\text { Distance education has } \\
\text { benefited my education } \\
\text { during the epidemic } \\
\text { period. }\end{array}$ & 3.15 & 1.458 & 106 & 20.9 & 68 & 13.4 & 96 & 18.9 & 118 & 23.2 & 120 & 23.6 \\
\hline
\end{tabular}




\begin{tabular}{|l|l|l|l|l|l|l|l|l|l|l|l|l|}
\hline $\begin{array}{l}\text { Except for compulsory } \\
\text { situations, I prefer face } \\
\text { to face education instead } \\
\text { of distance education. }\end{array}$ & 3.83 & 1.605 & 96 & 18.9 & 28 & 5.5 & 43 & 8.5 & 39 & 7.7 & 302 & 59.4 \\
\hline
\end{tabular}

In order to determine whether there is a significant difference in the opinions of students about distance education by gender, t-test was performed and the data regarding the findings are shown in Table 4.

Table 4. The Results of the t-test Conducted on the Opinions of Distance Education According to the Gender Variable

\begin{tabular}{|l|l|c|c|c|c|c|c|}
\hline & Gender & N & $\overline{\mathbf{x}}$ & SD & t & df & p \\
\hline $\begin{array}{l}\text { Students' views on } \\
\text { distance education }\end{array}$ & Female & 272 & 2.96 & 0.866 & \multirow{2}{*}{-2.074} & 506 & $\mathbf{0 . 0 3 9}^{*}$ \\
\cline { 2 - 8 }$* \mathrm{p}<0.05$ & Male & 236 & 3.12 & 0.876 & & \\
\hline
\end{tabular}

When Table 4 is examined, it is seen that the arithmetic mean scores of the answers given by the male participants to the questionnaire items are higher than the female participants (Male $\bar{x}$ $=3.12$, Female $\bar{x}=2.96$ ). As a result of the $t$-test, the difference was found to be significant. According to this result, it can be said that the opinions of male participants regarding distance education are more positive than female participants. The reason for this result may be that men generally have a more positive view of technology than cats. Many studies have concluded that men's attitudes towards technology are more positive than women [11-13].

ANOVA test was conducted in order to determine whether there is a significant difference in the opinions of students regarding distance education according to the age variable and the information about the findings is shown in Table 5.

Table 5. ANOVA Results According to the Age Variable of Student Views on Distance Education

\begin{tabular}{|c|c|c|c|c|c|c|}
\hline \multirow{10}{*}{$\begin{array}{l}\text { Students' views on } \\
\text { distance education }\end{array}$} & \multicolumn{3}{|c|}{ Age } & $\mathbf{N}$ & $\overline{\mathbf{x}}$ & SD \\
\hline & \multicolumn{3}{|l|}{$17-19$} & 44 & 2.82 & 0.976 \\
\hline & \multicolumn{3}{|l|}{$20-22$} & 67 & 2.98 & 0.477 \\
\hline & \multicolumn{3}{|l|}{$23-25$} & 291 & 3.03 & 0.824 \\
\hline & \multicolumn{3}{|l|}{26 and over } & 106 & 3.19 & 0.738 \\
\hline & \multicolumn{3}{|l|}{ Total } & 412 & 3.54 & 0.883 \\
\hline & Source of Variance & SS & df & MS & $\mathbf{F}$ & $\mathbf{p}$ \\
\hline & Between Groups & 4.934 & 3 & 1.645 & 2.169 & 0.091 \\
\hline & Within Groups & 382.198 & 504 & 0.758 & & \\
\hline & Toplam & 387.132 & 507 & & & \\
\hline
\end{tabular}

According to Table 5, as the ages of the participants' increase, their views on distance education change positively. The average scores $(\overline{\mathrm{x}}=2.82)$ of the participants between the ages of 17-19 are lower than the other age groups $(20-22 \overline{\mathrm{x}}=2.98,23-25 \overline{\mathrm{x}}=3.03,26$ and over $\overline{\mathrm{x}}=3.19)$. As a result of the ANOVA test conducted to determine whether the difference is significant, it was determined that the difference was not significant. The reason for this may be that there is not much difference between age groups and almost all of the participants are digital natives that grow with technology [14]. 


\section{CONCLUSIONS}

Today, the widespread use of internet technology has created diversity in distance education and has allowed courses to be held simultaneously. Especially, the fact that portable devices have internet technology and the use of the internet from these devices has given students more freedom in following the distance education lessons. Our research results have shown that $70.3 \%$ of students prefer mobile phones in internet connection, similar to the results of recent research [15-17].

Distance education is a type of education that is not done face to face using technological devices and individuals cannot communicate directly, and this situation negatively affects the social skills of individuals. Looking at the results of the research, it is seen that the participants have negative effects on the socialization of distance education. Face-to-face interaction can be used and learned as the main reasons that prevent socialization. A review of the research results reveals that the participants have negative effects on the socialization of distance education. It can be counted as the main reason preventing socialization, where face-to-face interaction can be used and learned [18-21].

Another result of our research is that students' views on distance education are unstable, supporting other research in the field $[18,22]$. In some studies, it was concluded that students expressed negative views against distance education [19,23], while another study determined that students had a positive opinion [24]. The study shows that men view distance education more positively than women [24]. Many previous studies show that there is no difference in the opinions of students regarding distance education by gender variable $[18,22,25,26]$. The reason why students do not have a positive view may be technical problems in distance education. Indeed, the participants stated that they had some technical problems in distance education [18-20]. In addition to these results, students find face-to-face education more effective than distance education and prefer face-to-face education over distance education [2628].

The constraints experienced during the pandemic made it impossible for educational activities to be carried out formally. In this process, the importance of distance education is once again understood. Distance education systems need to be developed in order to provide more effective training activities. For this purpose, solving technical problems experienced during participation in live lessons can increase the quality of education as well as student motivation. By performing training activities with blended learning, the negative effects of socialization can be eliminated and the flexibility provided by distance education can be maintained.

This study was carried out to obtain students' views on distance education. Researchers are recommended to conduct studies to determine teachers 'views on distance education or the effects of this process on students' academic achievement.

\section{REFERENCES}

[1] Kirik, A. M. (2014). Uzaktan eğitimin tarihsel gelişimi ve Türkiye'deki durumu, Marmara University Journal of Communication, 21: 73-94.

[2] Nizam, F. (2004). Eğitim-öğretimde kitle iletişim araçlarının kullanım olanakları ve avantajlar, Trabzon: KATÜ Akademik Bilişim 2004, 1-17. 
[3] Akdemir, Ö. (2011). Yükseköğretimimizde uzaktan eğitim, Journal of Higher Education and Science, 1(2): 69-71.

[4] Altiparmak, M., Kurt, İ. D. and Kapidere, M. (2011). E-Öğrenme ve uzaktan eğitimde açık kaynak kodlu öğrenme yönetim sistemleri. Malatya: XIII. Akademik Bilişim, 319-327.

[5] Demirli, C. and Aksogan, M. (2012). The effect of blended learning on the persistence of academic performance for computer education, The Journal of Instructional Technologies \&Teacher Education, 1(1): 111122.

[6] Keegan, D. (1986). The foundations of distance education. London: Croom Helm.

[7] Holmberg, B (1989). Theory and practice of distance education. London and New York: Routledge.

[8] Karasar, N. (2008). Bilimsel Araştırma Yöntemi. (18th edition) Ankara: Nobel Yayınevi.

[9] Basturk, S. and Tastepe, M. (2013). Bilimsel Araştırma Yöntemleri. (Chapter 5) Ankara: VizeYayıncılık.

[10] Uzgören, N. (2009). Bilimsel Araştırmalarda Kullanılan Temel İstatistiksel Yöntemler ve SPSS Uygulamaları. (3. Bask1), Kütahya.

[11] Aksogan, M. and Bulut-Ozek, M. (2020). Öğretmen Adaylarının Teknoloji Yeterlilikleri ile Teknolojiye Bakış Açısı Arasındaki İlişki, Gümüşhane Üniversitesi Sosyal Bilimler Enstitüsü Elektronik Dergisi, 11(2): 301311.

[12] Gurbuzoglu-Yalmanci, S. and Aydin, S. (2014). Ortaokul Öğrencilerinin Teknolojiye Yönelik Tutumlarının Bazı Değişkenler Açısından İncelenmesi, Ege Eğitim Dergisi, 15(1), 125-138.

[13] Sáinz, M., and López-Sáez, M. (2010). Gender differences in computer attitudes and the choice of technologyrelated occupations in a sample of secondary students in Spain, Computers \& Education, 54(2): 578-587.

[14] Prensky, M. (2001). Digital Natives, Digital Immigrants, On the Horizon, 9(5): 1-6.

[15] Calis-Duman, M. and Aksogan, M. (2018). Sosyal medya ve akademik başari: İnönü Üniversitesi öğrencileri üzerinde bir alan araştirmasi, Social Sciences Studies Journal, 4(18): 1624-1638.

[16] Karatepe, F., Kucukgençay, N. and Peker, B. (2020). Öğretmen adayları senkron uzaktan eğitime nasıl bakıyor? Bir anket çalışması, Journal of Social and Humanities Sciences Research, 7(53): 1262-1274.

[17] Sercemeli, M. and Kurnaz, E. (2020). COVID-19 Pandemi Döneminde Öğrencilerin Uzaktan Eğitim Ve Uzaktan Muhasebe Eğitimine Yönelik Bakiş Açilari Üzerine Bir Araştirma, Uluslararası Sosyal Bilimler Akademik Araştırmalar Dergisi, 4(1): 40-53.

[18] Birisci, S. (2013). Video konferans tabanlı uzaktan eğitme ilişkin öğrenci tutumları ve görüşleri, The Journal of Instructional Technologies \&Teacher Education, 1(2): 24-40.

[19] Kaleli-Yilmaz, G. and Guven, B. (2015). Öğretmen adaylarının uzaktan eğitime yönelik algılarının metaforlar yoluyla belirlenmesi, Turkish Journal of Computer and Mathematics Education, 6(2): 299-322.

[20] Tuncer, M. and Bahadir, F. (2017). Uzaktan eğitim programlarının bu programlarda öğrenim gören öğrenci görüşlerine göre değerlendirilmesi, The Journal of Educational Reflections, 1(2): 29-38.

[21] Karakus, N., Ucuzsatar, N., Karacaoglu, M. O., Esendemir, N. and Bayraktar, D. (2020). Türkçe öğretmeni adaylarının uzaktan eğitime yönelik görüşleri, RumeliDE Dil ve Edebiyat Araştırmaları Dergisi, (19): 220-241.

[22] Ates, A. and Altun, E. (2008). Bilgisayar öğretmeni adaylarının uzaktan eğitime yönelik tutumlarının çeşitli değişkenler açısından incelenmesi, Gazi Üniversitesi Eğitim Fakültesi Dergisi, 28(3): 125-145.

[23] Pepeler, E., Ozbek, R. and Adanır, Y. (2018). Uzaktan eğitim ile verilen ingilizce dersine yönelik öğrenci görüşleri: Muş Alparslan Üniversitesi örneği, Muş Alparslan Üniversitesi Sosyal Bilimler Dergisi, 6(3): 421-429. 
[24] Yenilmez, K., Turgut, M. and Balbağ, M.Z. (2017). Öğretmen adaylarının uzaktan eğitime yönelik tutumlarının bazı değişkenler açısından incelenmesi. Erzincan Üniversitesi Ĕ̈itim Fakültesi Dergisi, 19(2): 91107.

[25] Kirali, F.N. and Alıcı, B. (2016). Üniversite öğrencilerinin uzaktan eğitim algısına ilişkin görüşleri, İstanbul Aydın Üniversitesi Dergisi, 8(30): 55-83.

[26] Yalman, M. (2013). Eğitim fakültesi öğrencilerinin bilgisayar destekli uzaktan eğitim sistemi (MOODLE) memnuniyet düzeyleri, Turkish Studies, 8(8): 1395-1406.

[27] Ozgol, M., Sarikaya, I. and Ozturk, M. (2017). Örgün eğitimde uzaktan eğitim uygulamalarına ilişkin öğrenci ve öğretim elemanı değerlendirmeleri, Journal of Higher Education and Science, 7(2): 294-304.

[28] Tanyildizi, M. and Semerci, C. (2005). Çevrim içi eğitim uygulamlarına ilişkin öğretim elemanı ve öğrenci görüşlerinin belirlenmesi, Türk Eğitim Bilimleri Dergisi, 3(2): 421-429. 